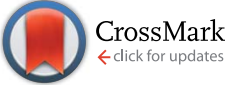

Cite this: RSC Adv., 2016, 6, 3899

Received 22nd October 2015 Accepted 10th December 2015

DOI: $10.1039 / c 5 r a 22141 b$

www.rsc.org/advances

\section{Copper(II) quinolinonato-7-carboxamido complexes as potent antitumor agents with broad spectra and selective effects $\uparrow$}

Radka Křikavová, Ján Vančo, Zdeněk Trávníček, ${ }^{*}$ Roman Buchtík and Zdeněk Dvořák

A series of five copper(॥) mixed-ligand complexes with the composition [Cu(qui $\left.{ }^{x}\right)$ (phen)] $\mathrm{NO}_{3} \cdot y \mathrm{H}_{2} \mathrm{O}(1$ to 5), where Hqui ${ }^{x}$ stands for 2-(4-amino-3,5-dichlorophenyl)-3-hydroxy-4(1H)-quinolinone-7-carboxamides with different $N$-substitutions: Hqui ${ }^{1}=N$-propyl (1), Hqui ${ }^{2}=N$-isobutyl (2), Hqui $^{3}=N$-cyclohexyl (3), Hqui $^{4}=N$-benzyl (4), and Hqui ${ }^{5}=N$-p-xylyl (5); phen $=1,10$-phenanthroline and $y=0$ or 1 , were synthesized, characterized and screened for in vitro antitumor activity on a panel of six human cancer cell lines, including osteosarcoma (HOS), breast adenocarcinoma (MCF7), malignant melanoma (G361), cervix carcinoma (HeLa), ovarian carcinoma (A2780) and cisplatin-resistant ovarian carcinoma (A2780R). All the complexes, except for limitedly soluble complex 4 , showed very potent cytotoxicity $\left(\mathrm{IC}_{50} \approx 1-\right.$ $7 \mu \mathrm{M})$; the best $I C_{50}$ value was found for complex 5 against $A 2780$, with $I C_{50}=0.6(1) \mu M$. Moreover, complex 5 was found to be non-toxic up to $50 \mu \mathrm{M}$ against non-malignant lung fibroblast cells (MRC-5); therefore, showing a promising selectivity index $\left[I C_{50}(M R C-5) / I C_{50}(A 2780)\right]$ that was higher than 80 . The complexes were also shown to bind to calf thymus DNA, interact with physiological levels of L-cysteine and act as chemical nucleases. It was additionally suggested that the species responsible for the biological activities of the prepared complexes were the $[\mathrm{Cu}(q u i)(p h e n)]^{+}$cations, or similar cationic species containing the $\{\mathrm{Cu}(\mathrm{phen})\}$ residue. The results clearly demonstrated that targeted structural optimization of the quinolinonato ligand in this class of complexes leads to compounds with high-level and broad-spectrum anticancer activity along with significantly increased selectivity.

\section{Introduction}

Metal-based cancer therapy has hitherto exclusively exploited the antitumour properties of platinum(II) complexes. Concretely, cisplatin and its derivatives (oxaliplatin and carboplatin) are currently well-established anticancer drugs used worldwide, whose therapeutic effects are based on the inhibition of cancer cell proliferation through binding to nuclear DNA. ${ }^{1-3}$ However, these platinum(II) complexes possess several limitations that complicate chemotherapy such as negative side effects (e.g. neurotoxicity, nephrotoxicity and emetogenesis) and intrinsic and/or acquired resistance phenomena. ${ }^{4,5}$ However, it is unambiguously the high therapeutic efficiency of these platinum(II)-based therapeutics, which has inspired many scientists

Regional Centre of Advanced Technologies and Materials, Division of Biological Active Complexes and Molecular Magnets, Faculty of Science, Palacký University, 17. listopadu 12, CZ-771 46 Olomouc, Czech Republic.E-mail: zdenek.travnicek@upol.cz $\dagger$ Electronic supplementary information (ESI) available: Fig. S1: ${ }^{1} \mathrm{H}$ and ${ }^{13} \mathrm{C}$ NMR spectra of $\mathrm{Hqui}^{4}$. Fig. S2: mid-FTIR spectra of $\mathrm{Hqui}^{4}$ (up) and complex 4 (down). Fig. S3: the electrophoreogram depicting the interactions of complexes 1 (lanes 1-3), 2 (lanes 4-6), 3 (lanes 7-9), and 5 (lanes 10-12) applied at $200 \mu \mathrm{M}$ concentration with pUC19 plasmid DNA. Blank sample contained only the native form of pUC19 plasmid DNA (lane 13). Fig. S4: dose-viability curves for complexes 1-3 and 5. See DOI: 10.1039/c5ra22141b to focus on the development of the next generation of transition metal complexes with both improved anticancer profiles and reduced negative side effects. ${ }^{6}$ One of the investigated approaches to decreasing the toxicity with respect to the platinum(II) complexes involves using essential transition metals as central atoms. Copper has been identified as a promising candidate, as it is an essential trace element found in all living organisms. Copper is involved in multiple functions of crucial enzymes $^{7}$ and works as a fundamental component of the redox system (transition between the $\mathrm{Cu}^{\mathrm{I}}$ and $\mathrm{Cu}^{\mathrm{II}}$ oxidation states). ${ }^{8}$ Furthermore, an additional benefit of copper being an endogenous essential metal lies in the already established metabolic pathways for copper-containing compounds, which could also play a role in modulating the general toxicity of prospective copper-based therapeutics.

The advantages of using copper as the central atom for the preparation of potential metallotherapeutics have already been exemplified in a number of copper complexes, particularly those involving planar polyheterocyclic ligands; these have shown notable cytotoxicity, with mechanisms of action related to varied modes of DNA interaction and redox metabolism alterations. ${ }^{9-12}$ The first reported $\mathrm{Cu}^{\mathrm{II}}$ complex of this group that was able to inhibit tumour growth in vivo (studied with the Landschutz ascites tumour model in mice) was shown to have 
the composition $\left.[\mathrm{Cu} \text { (tmphen })_{2}\right] \mathrm{Cl}_{2}$, where tmphen stands for 3,4,7,8-tetramethyl-1,10-phenanthroline. ${ }^{13}$ Since then, many $\mathrm{Cu}^{\text {II }}$ complexes containing 1,10-phenanthroline (phen) and other bidentate $\mathrm{N}$-donor heterocyclic ligands $(\mathrm{N}-\mathrm{N})$ and bidentate $\mathrm{O}$-donor ligands $(\mathrm{O}-\mathrm{O})$ of the type $[\mathrm{Cu}(\mathrm{N}-\mathrm{N})(\mathrm{O}-\mathrm{O})]^{n=0 / 1^{+}}$ have been synthesized and studied for their anticancer properties. Among these compounds, the Casiopeínas ${ }^{\circledR}$ series of $\mathrm{Cu}^{\mathrm{II}}$ mixed-ligand bis-chelated antineoplastic agents, containing phen, 2,2'-bipyridine (bpy) or their substituted derivatives, as well as essential amino acids or acetylacetone, ${ }^{14-18}$ stand out. Their remarkable antitumour activity in vitro and in vivo, as well as promising results from preclinical studies, have classified these complexes as auspicious candidates for clinical trials. ${ }^{19}$

In our recent studies, we have focused on Casiopeínas ${ }^{\circledR}$-like mixed-ligand $\mathrm{Cu}^{\mathrm{II}}$ complexes containing bidentate $N$-donor heterocyclic ligands (phen, bpy, or their $\mathrm{N}-\mathrm{N}$ derivatives), the 2-phenyl-3-hydroxy-4(1H)-quinolinonato ligand (qui) and nitrate or tetrafluoroborate counter anions $(\mathrm{Y})$ of the general composition $\left[\mathrm{Cu}(\right.$ qui) $\left.(\mathrm{N}-\mathrm{N})] \mathrm{Y} \cdot y \mathrm{H}_{2} \mathrm{O}\right] \cdot{ }^{20-22}$ These complexes were identified as promising cytotoxic agents against a broad spectrum of human cancer cell lines, with $\mathrm{IC}_{50}$ reaching micromolar to sub-micromolar values, e.g. the $\mathrm{IC}_{50}$ value against $\mathrm{A} 2780$ ovarian cancer cells equalled $0.36 \pm 0.05 \mu \mathrm{M}$ for $[\mathrm{Cu}($ qui)(mphen) $] \mathrm{BF}_{4} \cdot \mathrm{H}_{2} \mathrm{O}$ (mphen = 5-methyl-1,10-phenanthroline). Moreover, markedly lower cellular toxicities of the complexes to healthy cells were observed; the ratios of the effective concentration against cancer cells to the toxic concentration to primary human hepatocytes were up to $1: 40$. In general, the best selectivity index was observed for the complexes containing non-substituted phen as the $N$-donor ligand.

Quite recently, an extensive structure-cytotoxic activity relationship study was performed for 2-phenylsubstituted-3hydroxyquinolin-4(1H)-one-carboxamides, which showed that the carboxamide substitution plays a positive role in the tuning of cytotoxicity (the best derivatives showed submicromolar $\mathrm{IC}_{50}$ values against the CEM leukaemia cell line) and results in very favourable therapeutic indices (up to 40 for the derivatives used in this study). ${ }^{23}$ These encouraging results inspired us to extend our previous studies and elucidate whether and how the 2-(3,5-dichloro-4-amino)phenyl- and 7-alkylcarboxamidosubstitutions on the quinolinone skeleton may influence the biological activity of mixed-ligand complexes of the $\left[\mathrm{Cu}\left(\mathrm{qui}^{x}\right)\right.$ (phen)] $\mathrm{NO}_{3} \cdot y \mathrm{H}_{2} \mathrm{O}(\mathbf{1 - 5})$ type. Herein, we report the synthesis, thorough characterization, and results of biological activity evaluations, i.e. cytotoxicity screening against a panel of seven human cancer and non-malignant cell lines, as well as investigations of their interactions with DNA and sulphur-containing biomolecules, of a series of copper(II) complexes of the general composition $\left[\mathrm{Cu}\left(\mathrm{qui}^{x}\right)(\right.$ phen $\left.)\right] \mathrm{NO}_{3} \cdot y \mathrm{H}_{2} \mathrm{O}(\mathbf{1}-\mathbf{5}$, where $x=$ $1-5, y=0$ or 1 ).

\section{Experimental}

\subsection{Materials and methods}

Chemicals and solvents were purchased from Sigma-Aldrich Co. and Acros Organics Co. and were used as received. The 2phenyl-3-hydroxy-4(1H)-quinolinone-7-carboxamides (Hqui ${ }^{1-5}$ ) with $N$-substitution: Hqui $^{1}=N$-propyl, Hqui $^{2}=N$-isobutyl, $\mathrm{Hqui}^{3}=N$-cyclohexyl, $\mathrm{Hqui}^{4}=N$-benzyl, $\mathrm{Hqui}^{5}=N$ - $p$-xylyl, used as the starting materials for the preparation of complexes $\mathbf{1}$ to $\mathbf{5}$, were synthesized following a previously reported procedure; ${ }^{24}$ their purity was verified by elemental analysis, FTIR and NMR spectroscopy (Fig. S1 and S2, ESI†).

Elemental analysis (C, H, N) was carried out on a Flash EA-2000 Elemental Analyser (Thermo Finnigan). FTIR spectra were obtained on a Nexus 670 FTIR (ThermoNicolet) using the ATR technique in the range of $200-4000 \mathrm{~cm}^{-1}$. Electronic

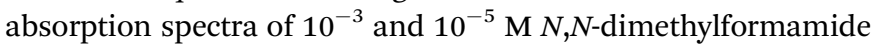
(DMF) solutions and diffuse-reflectance UV-Vis spectra were obtained with a Lambda 40 spectrometer (Perkin Elmer Instruments) in the range of 300-900 $\mathrm{nm}$. Mass spectra (MS) were obtained on an LCQ Fleet (ThermoFisher Scientific) spectrometer using the positive electrospray ionisation (ESI+) and full scan modes for $10^{-5} \mathrm{M}$ methanol solutions of 1-5. NMR spectra of $\mathrm{Hqui}^{1-5}$ were measured in DMF- $d_{7}$ on a Varian $400 \mathrm{MHz}$ NMR spectrometer at $298 \mathrm{~K}$. Tetramethylsilane (TMS) was used as the internal reference standard for the ${ }^{1} \mathrm{H}$ and ${ }^{13} \mathrm{C}$ NMR experiments. Simultaneous thermogravimetric (TG) and differential thermal (DTA) analyses were performed on an Exstar TG/DTA 6200 thermal analyser (Seiko Instruments Inc.). TG/DTA studies were carried out in platinum pans from ambient temperature to 800 ${ }^{\circ} \mathrm{C}$ with a $2.5{ }^{\circ} \mathrm{C} \min ^{-1}$ temperature gradient in dynamic air atmosphere $\left(100 \mathrm{~mL} \mathrm{~min}^{-1}\right)$. Conductivity experiments were performed on a Cond 340i/SET (WTW) in DMF $\left(10^{-3} \mathrm{M}\right.$, at $\left.25^{\circ} \mathrm{C}\right)$. The quantum chemical calculations were performed at the DFT level using the hybrid B3LYP functional with the LACVP+** basis set using Spartan'10 (version 1.1.0v4) software. ${ }^{25-27}$

\subsection{Synthesis of $\left[\mathrm{Cu}\left(\mathrm{qui}^{1}\right)(\mathrm{phen})\right] \mathrm{NO}_{3}(\mathbf{1}),\left[\mathrm{Cu}\left(\mathrm{qui}^{2}\right)(\mathrm{phen})\right]$} $\mathrm{NO}_{3}(2),\left[\mathrm{Cu}\left(\mathrm{qui}^{3}\right)(\mathrm{phen})\right] \mathrm{NO}_{3}(3),\left[\mathrm{Cu}\left(\mathrm{qui}^{4}\right)(\right.$ phen $\left.)\right] \mathrm{NO}_{3} \cdot \mathrm{H}_{2} \mathrm{O}$ (4) and $\left[\mathrm{Cu}\left(\mathrm{qui}^{5}\right)(\mathrm{phen})\right] \mathrm{NO}_{3}(5)$

1,10-Phenanthroline (phen) monohydrate (198 mg, $1 \mathrm{mmol}$ ) was dissolved in ethanol $(10 \mathrm{~mL})$, and the corresponding quinolinone $\left(\mathrm{Hqui}^{1-5}\right)(1 \mathrm{mmol})$ dispersed in ethanol $(30 \mathrm{~mL})$ was then added with stirring. A solution of $\mathrm{Cu}\left(\mathrm{NO}_{3}\right)_{2} \cdot 3 \mathrm{H}_{2} \mathrm{O}(242 \mathrm{mg}$, $1 \mathrm{mmol}$ ) in distilled water $(5 \mathrm{~mL})$ was slowly added to the resulting mixture with stirring. The reaction mixture was stirred at room temperature for a few hours until a solid product formed. The obtained solid was filtered, washed with a small amount of cold water and ethanol, and dried at $40{ }^{\circ} \mathrm{C}$ under an infrared lamp.

2.2.1. [Cu(qui $\left.{ }^{1}\right)\left(\right.$ phen)] $\mathrm{NO}_{3}$ (1). (565 mg, 79.5\%). Found: C, 52.3; $\mathrm{H}, 3.8 . ; \mathrm{N}, 11.4 \%$. Calc. for $\mathrm{C}_{31} \mathrm{H}_{24} \mathrm{~N}_{6} \mathrm{O}_{6} \mathrm{Cl}_{2} \mathrm{Cu}\left(M_{\mathrm{r}}=711.0\right)$ : C, 52.4; H, 3.4; N, 11.8\%. TG/DTA: decomposition began at $202{ }^{\circ} \mathrm{C}$, with subsequent exothermic effects with maxima centred at $266,282,329$ and $506{ }^{\circ} \mathrm{C}$, and finished at $537^{\circ} \mathrm{C} . \Lambda_{\mathrm{m}}$

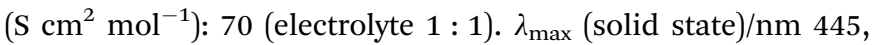
739. $\lambda_{\max }\left(10^{-5} \mathrm{M}\right.$ DMF solution) $) / \mathrm{nm} 425\left(\varepsilon / \mathrm{M}^{-1} \mathrm{~cm}^{-1} 9288\right)$. FTIR $\left(\nu, \mathrm{cm}^{-1}\right): 3307,3200,3070,2961,2934,2874,1664,1623$, 1572, 1541, 1492, 1452, 1429, 1376, 1314, 1254, 1184, 1148, 1040, 943, 895, 878, 847, 742, 720, 697, 653, 601, 584, 561, 513, 432, 337, 311, 244. ESI + MS: $m / z 647\left(\left[\mathrm{M}-\left(\mathrm{NO}_{3}\right)\right]^{+}, 100 \%\right), 243$ $\left([\mathrm{Cu}(\text { phen })]^{+}, 10 \%\right), 1296\left(\left[\left\{\mathrm{M}-\left(\mathrm{NO}_{3}\right)\right\}_{2}\right]^{+}, 2 \%\right)$. 
2.2.2. [Cu(qui $\left.{ }^{2}\right)($ phen) $] \mathrm{NO}_{3}$ (2). (615 mg, 84.8\%). Found: $52.7 ; \mathrm{H}, 3.6 ; \mathrm{N}, 11.6 \%$. Calc. for $\mathrm{C}_{32} \mathrm{H}_{26} \mathrm{~N}_{6} \mathrm{O}_{6} \mathrm{Cl}_{2} \mathrm{Cu}\left(M_{\mathrm{r}}=725.0\right)$ : C, 53.0; H, 3.6; N, 11.6\%. TG/DTA data: decomposition began at $186^{\circ} \mathrm{C}$, with subsequent exothermic effects with maxima at 266, 282,338 and $522{ }^{\circ} \mathrm{C}$, and finished at $587^{\circ} \mathrm{C} . \Lambda_{\mathrm{m}}\left(\mathrm{S} \mathrm{cm}^{2} \mathrm{~mol}^{-1}\right)$ : 70 (electrolyte $1: 1) . \lambda_{\max }$ (solid state) $/ \mathrm{nm} 445,751 . \lambda_{\max }\left(10^{-5} \mathrm{M}\right.$ DMF solution)/nm $437\left(\varepsilon / \mathrm{M}^{-1} \mathrm{~cm}^{-1} 8470\right)$. FTIR ( $\left.\nu, \mathrm{cm}^{-1}\right): 3311$, 3238, 3200, 3068, 2959, 2930, 2872, 1624, 1575, 1543, 1490, 1453, 1431, 1372, 1312, 1257, 1184, 1146, 1087, 1042, 942, 894, 878, 847, 744, 720, 693, 655, 600, 582, 560, 501, 434, 335, 311. ESI + MS: $m / z 661\left(\left[\mathrm{M}-\left(\mathrm{NO}_{3}\right)\right]^{+}, 100 \%\right), 1322\left(\left[\left\{\mathrm{M}-\left(\mathrm{NO}_{3}\right)\right\}_{2}\right]^{+}\right.$, $30 \%), 243\left([\mathrm{Cu}(\text { phen })]^{+}, 18 \%\right)$.

2.2.3. $\left[\mathrm{Cu}\left(\right.\right.$ qui $\left.^{3}\right)($ phen $\left.)\right] \mathrm{NO}_{3}$ (3). (598 mg, 79.6\%). Found: $\mathrm{C}$, $54.1 ; \mathrm{H}, 3.7 ; \mathrm{N}, 11.0 \%$. Calc. for $\mathrm{C}_{34} \mathrm{H}_{28} \mathrm{~N}_{6} \mathrm{O}_{6} \mathrm{Cl}_{2} \mathrm{Cu}\left(M_{\mathrm{r}}=751.1\right)$ : C, 54.4; H, 3.8; N, 11.2\%. TG/DTA: decomposition began at 188 ${ }^{\circ} \mathrm{C}$, with subsequent exothermic effects with maxima centred at 275, 283, 327 and $482{ }^{\circ} \mathrm{C}$, and finished at $545{ }^{\circ} \mathrm{C} . \Lambda_{\mathrm{m}}\left(\mathrm{S} \mathrm{cm}^{2}\right.$ $\mathrm{mol}^{-1}$ ): 65 (electrolyte $\left.1: 1\right) . \lambda_{\max }\left(\right.$ solid state)/nm 425, 789. $\lambda_{\max }$ $\left(10^{-5} \mathrm{M}\right.$ DMF solution)/nm $424\left(\varepsilon / \mathrm{M}^{-1} \mathrm{~cm}^{-1} 12660\right)$. FTIR $\left(\nu, \mathrm{cm}^{-1}\right): 3319,3109,3068,2930,2855,1620,1573,1544,1520$, 1494, 1453, 1431, 1376, 1314, 1255, 1182, 1150, 1111, 1082, 1040, 943, 892, 876, 848, 830, 789, 742, 722, 698, 653, 619, 588, 563, 495, 471, 436, 332, 310, 259. ESI + MS: $m / z 687\left(\left[\mathrm{M}-\left(\mathrm{NO}_{3}\right)\right]^{+}\right.$, $100 \%), 1376\left(\left[\left\{\mathrm{M}-\left(\mathrm{NO}_{3}\right)\right\}_{2}{ }^{+}, 15 \%\right), 243\left([\mathrm{Cu}(\text { phen })]^{+}, 9 \%\right)\right.$.

2.2.4. $\left[\mathrm{Cu}\left(\right.\right.$ qui $\left.^{4}\right)($ phen $\left.)\right] \mathrm{NO}_{3} \cdot \mathrm{H}_{2} \mathrm{O} \quad$ (4). (535 mg, $\left.70.5 \%\right)$. Found: C, 53.9; H, 3.4; N, 10.5\%. Calc. for $\mathrm{C}_{35} \mathrm{H}_{24} \mathrm{~N}_{6} \mathrm{O}_{6} \mathrm{Cl}_{2}$ $\mathrm{Cu} \cdot \mathrm{H}_{2} \mathrm{O}\left(M_{\mathrm{r}}=777.1\right): \mathrm{C}, 54.1 ; \mathrm{H}, 3.4 ; \mathrm{N}, 10.8 \%$. TG/DTA: a weight loss of $2.4 \%$ is accompanied by an endothermic effect with the minimum at $90{ }^{\circ} \mathrm{C}\left(2.3 \%\right.$ calcd for $\left.\mathrm{H}_{2} \mathrm{O}\right)$; the decomposition of the non-solvated complex began at $196{ }^{\circ} \mathrm{C}$, with subsequent exothermic effects with maxima centred at 259, 288,332 and $472{ }^{\circ} \mathrm{C}$, and finished at $577^{\circ} \mathrm{C} . \Lambda_{\mathrm{m}}\left(\mathrm{S} \mathrm{cm}^{2} \mathrm{~mol}^{-1}\right)$ : 70 (electrolyte $1: 1) . \lambda_{\max }$ (solid state) $/ \mathrm{nm} 451,778 . \lambda_{\max }\left(10^{-5} \mathrm{M}\right.$ DMF solution)/nm $427\left(\varepsilon / \mathrm{M}^{-1} \mathrm{~cm}^{-1} 10\right.$ 129). FTIR $\left(\nu, \mathrm{cm}^{-1}\right)$ : 3456, 3319, 3198, 3084, 3063, 3034, 3007, 2967, 2930, 1619, 1572, 1542, 1378, 1308, 1253, 1226, 1180, 1145, 1109, 1082, 1039, 946, 889, 876, 845, 790, 740, 720, 698, 653, 603, 565, 557, 514, 501, 460, 435, 413, 303, 247. ESI + MS: $m / z 695\left(\left[\mathrm{M}-\left(\mathrm{NO}_{3}\right)\right]^{+}, 100 \%\right)$, $1390\left(\left[\left\{\mathrm{M}-\left(\mathrm{NO}_{3}\right)\right\}_{2}{ }^{+}, 20 \%\right), 243\left([\mathrm{Cu}(\text { phen })]^{+}, 10 \%\right)\right.$.

2.2.5. [Cu(qui $\left.{ }^{5}\right)($ phen $\left.)\right] \mathrm{NO}_{3}$ (5). (524 mg, 67.8\%). Found: C, 55.6; H, 3.4; N, 10.7\%. Calc. for $\mathrm{C}_{36} \mathrm{H}_{26} \mathrm{~N}_{6} \mathrm{O}_{6} \mathrm{Cl}_{2} \mathrm{Cu}\left(M_{\mathrm{r}}=773.1\right)$ : C, 55.9; H, 3.4; N, 10.9. TG/DTA: decomposition began at $173{ }^{\circ} \mathrm{C}$, with subsequent exothermic effects with maxima centred at 264 , 291, 335 and $504{ }^{\circ} \mathrm{C}$, and finished at $584{ }^{\circ} \mathrm{C} . \Lambda_{\mathrm{m}}\left(\mathrm{S} \mathrm{cm}^{2} \mathrm{~mol}^{-1}\right)$ : 65 (electrolyte $1: 1) . \lambda_{\max }$ (solid state) $/ \mathrm{nm} \mathrm{448,} \mathrm{773.} \lambda_{\max }\left(10^{-5} \mathrm{M}\right.$ DMF solution)/nm $424\left(\varepsilon / \mathrm{M}^{-1} \mathrm{~cm}^{-1} 10\right.$ 941). FTIR $\left(\nu, \mathrm{cm}^{-1}\right)$ : 3331, 3066, 2946, 2924, 2863, 1621, 1575, 1545, 1492, 1455, 1429, 1381, 1312, 1279, 1252, 1227, 1181, 1147, 1111, 1040, 947, 894, 878, 848, 785, 759, 742, 722, 694, 655, 615, 584, 565, 492, 477, 436, 344, 318, 246. ESI + MS: $m / z 709\left(\left[\mathrm{M}-\left(\mathrm{NO}_{3}\right)\right]^{+}, 100 \%\right), 1418$ $\left(\left[\left\{\mathrm{M}-\left(\mathrm{NO}_{3}\right)\right\}_{2}{ }^{+}, 23 \%\right), 243\left([\mathrm{Cu}(\text { phen })]^{+}, 11 \%\right)\right.$.

\subsection{Biological activity}

2.3.1. In vitro cytotoxicity testing. $\mathrm{Cu}^{\mathrm{II}}$ complexes $\mathbf{1 - 5}$, together with cisplatin, the antineoplastic drug used as a reference standard, were evaluated for their in vitro cytotoxicity by the MTT (3-(4,5-dimethylthiazol-2-yl)-2,5-diphenyltetrazolium bromide) assay against six human cancer cell lines, namely, osteosarcoma (HOS; ECACC no. 87070202), breast adenocarcinoma (MCF7; ECACC no. 86012803), cervix epitheloid carcinoma (HeLa; ECACC no. 93021013), malignant melanoma (G361; ECACC no. 88030401), ovarian carcinoma (A2780; ECACC no. 93112519), cisplatin-resistant ovarian carcinoma (A2780R; ECACC no. 93112517), and non-malignant human foetal lung fibroblast cells (MRC-5; ECACC no. 84101801). The cell lines were purchased from the European Collection of Cell Cultures (ECACC; Prague, Czech Republic). The cells were maintained in a humidified incubator $\left(37{ }^{\circ} \mathrm{C}, 5 \% \mathrm{CO}_{2}\right)$. The cells were treated with the tested compounds (1-5 and cisplatin) at the $0.01,0.1,1.0,5.0,25.0$ and $50 \mu \mathrm{M}$ concentrations for $24 \mathrm{~h}$, using multi-well culture plates of 96 wells. In parallel, the cells were treated with vehicle (DMF; 0.1\% v/v) and Triton X-100 (1\% $\mathrm{v} / \mathrm{v}$ ) to assess the minimal (i.e. positive control) and maximal (i.e. negative control) cell damage, respectively. The cells were incubated with MTT for 3-4 h; after removing the medium and washing the cells with phosphate buffer solution, formazan dye was dissolved in DMF containing 1\% ammonia. The MTT assay absorbance was measured spectrophotometrically at $540 \mathrm{~nm}$ (TECAN, Schoeller Instruments LLC). The data were expressed as the percentage of viability, where $100 \%$ and $0 \%$ represent the treatments with DMF and Triton X-100, respectively. ${ }^{21}$ The cytotoxicity data from the cell lines were obtained from three independent experiments using cells from different passages, while each experiment was performed in triplicate. The obtained $\mathrm{IC}_{50} \pm \mathrm{SD}(\mu \mathrm{M})$ values, together with their standard deviations (SD), were calculated from the dose-viability curves by linear regression analysis of the area containing the steepest and most linear descent of the curve (see the dose-viability curves in the ESI, Fig. S4 $\dagger$ ). The significance of the differences between the results was assessed by ANOVA, with $p<0.05$ considered to be significant. ${ }^{28}$

2.3.2. Interaction with calf thymus DNA (CT-DNA) assessed by fluorescence titration. The interaction of the complexes with calf thymus DNA (CT-DNA) was assessed by the ethidium bromide (EB) displacement fluorescence assay. The fluorescence quenching experiments were performed in $\mathrm{Tris} / \mathrm{HCl}$ buffer [tris(hydroxymethyl) aminomethane] containing $5 \mathrm{mM}$ Tris and $50 \mathrm{mM} \mathrm{NaCl}$, adjusted to $\mathrm{pH} 7.2$ by the addition of $\mathrm{HCl}$, and were carried out by the addition of the complexes to a sample solution containing EB-DNA. The spectra were obtained with an excitation wavelength of $520 \mathrm{~nm}$ in the emission range of $550-750 \mathrm{~nm}$. In the fluorescence quenching spectra, the reduction in emission intensity measures the binding propensity of the complex to CT-DNA. The Stern-Volmer quenching constant $\left(K_{\text {sv }}\right)$ and the apparent binding constant $\left(K_{\text {app }}\right)$ were calculated using the equations $F_{0} / F=1+K_{\mathrm{sv}} r$ and $K_{\mathrm{EB}}[\mathrm{EB}]=K_{\mathrm{app}}[$ Complex], where $F_{0}$ and $F$ correspond to the fluorescence intensities of EB-DNA in the absence and presence of the complex, respectively; $r$ is the ratio of the total concentration of the complex to that of DNA; $K_{\mathrm{EB}}=1 \times 10^{7} \mathrm{M}^{-1}$; $[\mathrm{EB}]=5 \mu \mathrm{M}$; and [Complex] is the concentration of the complex at a $50 \%$ reduction of the emission intensity of $\mathrm{EB}^{29}$ 
2.3.3. pUC19 plasmid DNA cleavage. Supercoiled plasmid DNA, pUC19 (2686 bp, $1750 \mathrm{kDa}$ ), was obtained from Invitrogen (Netherlands) and solubilised in storage buffer (10 mM Tris$\mathrm{HCl}, 5 \mathrm{mM} \mathrm{NaCl}, 0.1 \mathrm{mM}$ EDTA, $\left.\mathrm{pH}=7.4,250 \mu \mathrm{g} \mathrm{mL}{ }^{-1}\right)$. Supercoiled plasmid pUC19 (300 ng per reaction, corresponding to a concentration of $23 \mu \mathrm{M}$ calculated for the base pairs) was mixed with different concentrations $(20 \mu \mathrm{M}, 100 \mu \mathrm{M}$, and $200 \mu \mathrm{M}$ ) of the selected representative complex 5 (with different setups, either in the presence or in the absence of the reducing agent L-ascorbic acid (at a concentration of $1.66 \mathrm{mM}$ )) in TBE buffer (containing $89 \mathrm{mM}$ Tris, $89 \mathrm{mM}$ boric acid, and $2 \mathrm{mM}$ EDTA). The reaction mixtures were incubated at $37{ }^{\circ} \mathrm{C}$ for $1 \mathrm{~h}$ and then analysed by $0.8 \%$ agarose gel electrophoresis and detected with EB staining. The electrophoretogram was analysed with the software AlphaEaseFC, version 4.0.0.34 (Alpha Innotech, USA), and the relative percentages of the circular (CCC), one strand nicked (OC), and linear (L) forms were evaluated. The quantitative parameter of total DNA cleavage was calculated as the percentage of the integrated density of the cleaved forms (OC-form $+2 \times$ L-form) from the sum of the integrated densities of all identified forms of DNA (CCC-form + OC-form $+2 \times$ L-form). Each experiment was performed in triplicate, and the presented results are the mean values calculated from all the experiments.

2.3.4. Interactions with sulphur-containing biomolecules assessed by ESI-MS. The interaction experiments between the representative complex $\mathbf{5}$ and the mixture of physiological levels of L-cysteine and L-glutathione $(290 \mu \mathrm{M} \text { and } 6 \mu \mathrm{M} \text {, respectively })^{30}$ were performed on a ThermoFinnigan LTQ Fleet Ion-Trap mass spectrometer using the positive ionization mode. The flowinjection analysis method was used to introduce the reaction system $(20 \mu \mathrm{L}$ spikes) into the mass spectrometer, while the acetonitrile (gradient grade) was used as a mobile phase. The ESI source was set up as follows: the source voltage was $4.9 \mathrm{kV}$, the vaporizer temperature was $160{ }^{\circ} \mathrm{C}$, the capillary temperature was $275{ }^{\circ} \mathrm{C}$, the sheath gas flow rate was $20 \mathrm{~L} \mathrm{~min}^{-1}$, and the auxiliary gas flow rate was $5 \mathrm{~L} \mathrm{~min}^{-1}$. The system was calibrated according to the manufacturer's specifications, and no further tuning was needed. In addition, solutions containing a mixture of L-cysteine and L-glutathione and a solution of complex 5 in methanol/water $(1: 1, \mathrm{v} / \mathrm{v})$ were used as reference samples. The interacting system was analysed immediately after preparation $(0 \mathrm{~h})$, and was then analysed 1, 12, and $24 \mathrm{~h}$ after the solutions of complex 5 and the sulphur-containing biomolecules were mixed.

\section{Results and discussion}

\subsection{General properties}

Yellow-green copper(II) complexes of the general composition $\left[\mathrm{Cu}\left(\right.\right.$ qui $\left.^{1-5}\right)($ phen $\left.)\right] \mathrm{NO}_{3} \cdot y \mathrm{H}_{2} \mathrm{O}(\mathbf{1}-5 ; x=0-1)$ were synthesized via the reaction of 1,10-phenanthroline (phen) monohydrate and the corresponding 2-(4-amino-3,5-dichlorophenyl)-3-hydroxy$4(1 H)$-quinolinone-7-carboxamides with $N$-substitution, i.e. Hqui $^{1}=N$-propyl (1), Hqui ${ }^{2}=N$-isobutyl (2), Hqui $^{3}=N$-cyclohexyl (3), Hqui $^{4}=N$-benzyl (4), and Hqui ${ }^{5}=N$ - $p$-xylyl (5), with $\mathrm{Cu}\left(\mathrm{NO}_{3}\right)_{2} \cdot 3 \mathrm{H}_{2} \mathrm{O}$ in an ethanol/water mixture $(11: 1, \mathrm{v} / \mathrm{v})$ in a 1:1:1 molar ratio, with yields of $68-85 \%$ (Scheme 1). According to the conductivity measurements, complexes 1-5 behaved as electrolytes of the $1: 1$ type in $10^{-3} \mathrm{M}$ DMF solution with conductivity values of $c a .70 \mathrm{~S} \mathrm{~cm}^{2} \mathrm{~mol}^{-1}$. Furthermore, all the ESI+ mass spectra of the studied compounds contained the peaks of the corresponding complex $\left[\mathrm{Cu}\left(\text { qui }^{1-5}\right)(\text { phen })\right]^{+}$cations with a relative intensity of $100 \%$, thus providing evidence regarding the composition of $\mathbf{1}$ to $\mathbf{5}$. In addition, the peaks of the fragments of the dimeric species $\left[\left\{\mathrm{Cu}\left(\mathrm{qui}^{1-5}\right)(\mathrm{phen})\right\}_{2}\right]^{+}$as well as a peak corresponding to $\left[\mathrm{Cu}(\text { phen) }]^{+}\right.$at $243.0 \mathrm{~m} / z$ (calc. 243.0) were detected in the spectra of all the complexes, thus suggesting the same fragmentation patterns for the studied compounds.

The presence of the water molecule of crystallization in the monohydrated complex $\mathbf{4}$ was confirmed by simultaneous TG/DTA analysis. The calculated and experimental data regarding the crystal water elimination were found to be in good accordance (calcd/found 2.4/2.3\%). All the other complexes were found to be thermally stable up to $c a \cdot 180-200{ }^{\circ} \mathrm{C}$. The course of the thermal degradation of all the complexes above $200{ }^{\circ} \mathrm{C}$ was analogous, proceeding without the formation of any thermally stable intermediates, and characterized by four exothermic effects on the DTA curve. The final products of degradation (probably associated with the formation of $\mathrm{CuO}$ ) formed at ca. $540-580{ }^{\circ} \mathrm{C}$. The thermal decomposition data are listed in Section 2.3.

\subsection{UV-Vis and FTIR spectral characterizations}

The electronic spectra of the $\mathrm{Cu}^{\mathrm{II}}$ complexes $\mathbf{1}$ to $\mathbf{5}$ were measured in the 300 to $900 \mathrm{~nm}$ region, both in the solid state and in DMF solutions $\left(10^{-3}\right.$ and $\left.10^{-5} \mathrm{M}\right)$. The diffusereflectance spectra of the complexes exhibited one intensive well-defined absorption maximum centred at 425-451 nm, assignable to the charge-transfer transitions (CT), and one very broad maximum in the range of 739-789 $\mathrm{nm}$, which can be attributed to $\mathrm{d}-\mathrm{d}$ transitions of the ${ }^{2} \mathrm{~B}_{1 \mathrm{~g}} \rightarrow{ }^{2} \mathrm{E}_{\mathrm{g}},{ }^{2} \mathrm{~B}_{1 \mathrm{~g}} \rightarrow{ }^{2} \mathrm{~B}_{2 \mathrm{~g}}$, and ${ }^{2} \mathrm{~B}_{1 \mathrm{~g}} \rightarrow{ }^{2} \mathrm{~A}_{1 \mathrm{~g}}$ types, characteristic of copper(II) complexes with distorted square-planar arrangements. ${ }^{31}$ The measured UV-Vis spectra of the $10^{-5} \mathrm{M}$ DMF solutions of 1-5 were dominated by CT transitions observed in a similar region, at $425 \mathrm{~nm}(\mathbf{1})$, $437 \mathrm{~nm}$ (2), $424 \mathrm{~nm}(3), 427 \mathrm{~nm}$ (4) and $424 \mathrm{~nm}$ (5). The maxima
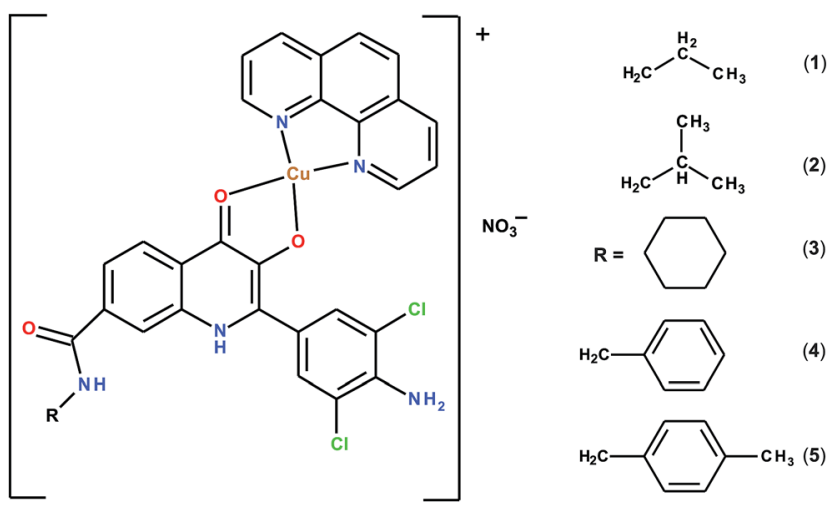

Scheme 1 The general structural formula of complexes 1-5. 
corresponding to the $\mathrm{d}-\mathrm{d}$ transitions with low absorbance values could be detected as unintensive shoulder bands only in the DMF solutions with $c \geq 10^{-3} \mathrm{M}$. In comparison with the solid state spectra, these maxima were shifted to lower wavelengths ranging from 599 to $611 \mathrm{~nm}$ (molar absorption coefficients equalling 81-156 $\mathrm{M}^{-1} \mathrm{~cm}^{-1}$ ) (Fig. 1). This shift is most likely connected with a change in the coordination geometry around the metal as a result of the coordination of solvent molecules to the copper(II) centre in the solution, which was confirmed by EPR spectroscopy for structurally analogous complexes in our previous study. ${ }^{20}$

FTIR spectra of the complexes were obtained in the region of $150-4000 \mathrm{~cm}^{-1}$. The interpretation of the spectra, made also in comparison with the spectra of $\mathrm{Hqui}^{1-5}$ and phen, indirectly confirmed the coordination of both types of organic ligands to the copper(II) atom. In the region of $2800-3500 \mathrm{~cm}^{-1}$, bands for the characteristic stretching vibrations of $\nu(\mathrm{N}-\mathrm{H})$ were identified at 3307-3331 $\mathrm{cm}^{-1}, \nu(\mathrm{C}-\mathrm{H})_{\mathrm{ar}}$ at $3063-3109 \mathrm{~cm}^{-1}$, and $\nu(\mathrm{C}-\mathrm{H})_{\mathrm{aliph}}$ at $2855-2959 \mathrm{~cm}^{-1}$. The spectrum of monohydrated complex 4 additionally showed a broad band at $3456 \mathrm{~cm}^{-1}$, assignable to $\nu(\mathrm{O}-\mathrm{H})$ originating from the water molecule of crystallization. Furthermore, two characteristic carbonyl group bands were clearly observed in the spectra of 1-5. A weak to medium intensity band in the region of $1642-1664 \mathrm{~cm}^{-1}$ could be assigned to the stretching amide carbonyl vibration, whereas the strong bands at $1619-1624 \mathrm{~cm}^{-1}$ are assignable to the qui carbonyl group in the position 4 of the heterocycle. The aromatic $\nu(\mathrm{C} \cdots \mathrm{C})_{\text {ring }}$ vibrations of the phen ring can be found between 1572 and $1575 \mathrm{~cm}^{-1}$ and in the region of 1429$1431 \mathrm{~cm}^{-1}$. Very strong characteristic bands of the qui aromatic $\nu(\mathrm{C} \cdots \mathrm{C})_{\text {ring }}$ vibrations appeared at 1490-1494 $\mathrm{cm}^{-1}$. The medium intensity band in the region of $1372-1381 \mathrm{~cm}^{-1}$ should be assigned to the qui $\nu(\mathrm{CNH})$ vibration. The uncoordinated nitrate group $\nu_{3}\left(\mathrm{NO}_{3}\right)$ bands were observed between 1308 and

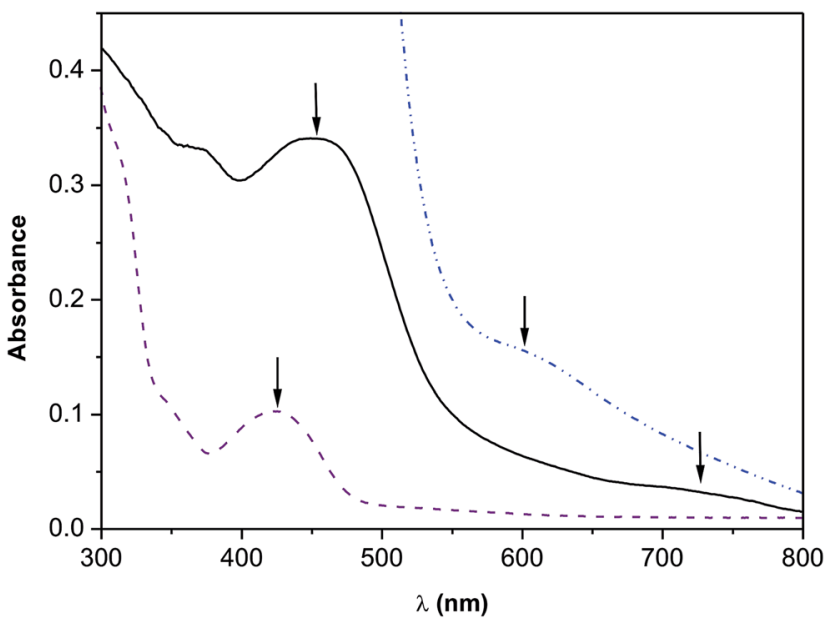

Fig. 1 UV-Vis spectra of complex 1 in the range of $300-800 \mathrm{~nm}$ : diffuse reflectance spectrum (solid black line); $10^{-5}$ M DMF solution spectrum (violet dashed line); $10^{-3} \mathrm{M}$ DMF solution spectrum (blue dash-dotted line). $\lambda_{\max }$ (solid state, $\left.\mathrm{nm}\right): 445,739 . \lambda_{\max }\left(10^{-5} \mathrm{M} \mathrm{DMF}\right.$ solution, $\mathrm{nm}) / \varepsilon\left(\mathrm{M}^{-1} \mathrm{~cm}^{-1}\right): 425 / 9288 . \lambda_{\max }\left(10^{-3} \mathrm{M} \mathrm{DMF}\right.$ solution, $\left.\mathrm{nm}\right) /$ $\varepsilon\left(\mathrm{M}^{-1} \mathrm{~cm}^{-1}\right): 605 / 156$. Maxima are indicated with black arrows.
$1314 \mathrm{~cm}^{-1}$. Two bands were also detected at $845-848 \mathrm{~cm}^{-1}$ and $720-722 \mathrm{~cm}^{-1}$, which are characteristic of the phen ligand (Fig. S2, ESI $\dagger$ ). In the far-IR region, the medium bands at $303-318 \mathrm{~cm}^{-1}$ could be attributed to $\nu(\mathrm{Cu}-\mathrm{N})$, whereas the peaks at $560-565$ and $492-513 \mathrm{~cm}^{-1}$ could be connected with the stretching vibrations of $\nu(\mathrm{Cu}-\mathrm{O}) .{ }^{32-34}$

\subsection{Quantum chemical calculations}

The X-ray structures of two complexes, $\left[\mathrm{Cu}(\right.$ qui)(phen) $] \mathrm{NO}_{3} \cdot \mathrm{H}_{2} \mathrm{O}$ and $\left[\mathrm{Cu}\right.$ (qui)(ambpy)] $\mathrm{NO}_{3}$ (ambpy = bis(2-pyridyl)amine), with analogous compositions of 1-5 have been already reported. ${ }^{20}$ Several attempts (including slow evaporation of the reaction solution or mother liquor at varied temperatures and diffusion of diethyl ether to saturated ethanol/DMF solution) were made to obtain suitable crystals of 1-5 for single crystal X-ray analysis; however, all employed methods were unsuccessful. In an effort to confirm the composition of 1-5 suggested by the results of the various analytical methods described above and to predict the molecular structure of the prepared complexes, a model for DFT calculation was built on the basis of the structural similarities of the complexes with $\left[\mathrm{Cu}(\right.$ qui)(phen) $] \mathrm{NO}_{3} \cdot \mathrm{H}_{2} \mathrm{O}$ and $[\mathrm{Cu}$ (qui)(ambpy) $] \mathrm{NO}_{3} \cdot{ }^{20}$ The geometry of the complex cation of 3 was optimized at the DFT level using the hybrid B3LYP functional with the LACVP+** basis set. The optimized geometry of $\left[\mathrm{Cu}\left(\mathrm{qui}^{3}\right)(\text { phen })\right]^{+}$is shown in Fig. 2 . The copper(II) atom is tetracoordinated by one bidentate $\mathrm{O}, \mathrm{O}$-coordinated qui ${ }^{3}\left(\mathrm{Hqui}^{3}=\right.$ 2-(4-amino-3,5-dichlorophenyl)- $N$-cyclohexyl-3-hydroxy-4(1H)quinolinone-7-carboxamide) and one bidentate $N, N$-coordinated phen. The $\mathrm{Cu}-\mathrm{N}$ bonds $(\mathrm{Cu}-\mathrm{N} 1=2.043 \AA$; $\mathrm{Cu}-\mathrm{N} 2=$ $2.043 \AA$ ) were found to be rather longer than the $\mathrm{Cu}-\mathrm{O}$ bonds $(\mathrm{Cu}-\mathrm{O} 1=1.916 \AA$; $\mathrm{Cu}-\mathrm{O} 2=1.941 \AA)$, which is in agreement with the bond length comparison in the vicinity of the metal centre in the structurally related complex [Cu(qui)(phen)] $\mathrm{NO}_{3} \cdot \mathrm{H}_{2} \mathrm{O}$ (further abbreviated as CuQ). ${ }^{20}$ However, the calculated bond lengths in the vicinity of the central atom were found

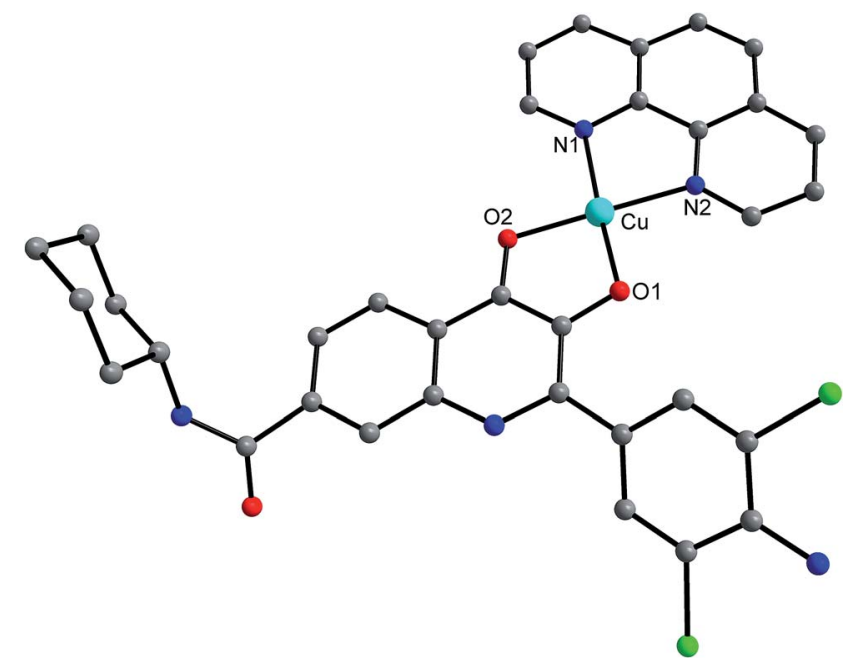

Fig. 2 The geometry of the complex $\left[\mathrm{Cu}\left(\right.\right.$ qui $\left.{ }^{3}\right)(\text { phen) }]^{+}$cation of 3 optimized at the B3LYP/LACVP+** level of theory. H-atoms were omitted for clarity. 
to be slightly greater than those found in the X-ray structure of $\mathrm{CuQ}(\mathrm{Cu}-\mathrm{N} 1=1.988(2) \AA$ 的 $\mathrm{Cu}-\mathrm{N} 2=1.978(2) \AA ; \mathrm{Cu}-\mathrm{O} 1=$ $1.892(2) \AA ; \mathrm{Cu}-\mathrm{O} 2=1.916(2) \AA)$. The geometry around the copper(II) atom in $\mathbf{4}$ could be described as distorted squareplanar; the $\mathrm{O} 1-\mathrm{Cu}-\mathrm{N} 1$ and $\mathrm{O} 2-\mathrm{Cu}-\mathrm{N} 2$ angles were equal to $177.28^{\circ}$ and $175.34^{\circ}$, respectively.

\subsection{In vitro cytotoxicity}

In our previous study, dealing with mixed-ligand $\mathrm{Cu}^{\mathrm{II}}$ complexes ${ }^{20-22}$ involving the $\mathrm{CuN}_{2} \mathrm{O}_{2}$ donor set, it was demonstrated that the 2-phenyl-3-hydroxy-4(1H)-quinolinone skeleton (Hqui) represents a promising $\mathrm{O}, \mathrm{O}$-donor ligand for Casiopeínas ${ }^{\circledR}$-like anticancer complexes, which represented the motivation for the study of complexes 1-5 presented herein.

Complexes 1-5 and cisplatin, used as a standard, were screened for in vitro cytotoxicity against osteosarcoma (HOS), breast adenocarcinoma (MCF7), cervix epithelioid carcinoma (HeLa), malignant melanoma (G361), ovarian carcinoma (A2780), cisplatin-resistant ovarian carcinoma (A2780R) and non-malignant human fibroblast (MRC5) cells. In the case of 4, the testing was limited by the low solubility of the complex in the medium used; in this case, the $\mathrm{IC}_{50}$ was expressed as $>5.0 \mu \mathrm{M}$. Otherwise, all the tested complexes exhibited dosedependent cytotoxicity against all the cancer cell lines, reaching low-micromolar or sub-micromolar $\mathrm{IC}_{50}$ values. Complexes 1-3 and 5 were significantly more cytotoxic (ANOVA, $p<0.05$ ) against HOS than cisplatin $\left(\mathrm{IC}_{50}=18.9 \pm 1.7 \mu \mathrm{M}\right)$. Against MCF7, only 1 and 2 showed IC $_{50}$ values significantly lower than cisplatin $\left(\mathrm{IC}_{50}=17.9 \pm 3.5 \mu \mathrm{M}\right)$. These values are comparable with those obtained for the structurally related complex $[\mathrm{Cu}$ (qui)(phen) $] \mathrm{NO}_{3} \cdot \mathrm{H}_{2} \mathrm{O}(\mathrm{CuQ})$, involving non-substituted qui, with $\mathrm{IC}_{50}=4.3 \pm 0.1 \mu \mathrm{M}$ (HOS) and $7.3 \pm 2.3 \mu \mathrm{M}$ (MCF7). ${ }^{20}$ The viability of HeLa cells, which were not sensitive to cisplatin up to the highest tested concentration $\left(\mathrm{IC}_{50}>50 \mu \mathrm{M}\right)$, was reduced comparably by all the complexes, including $\mathrm{CuQ}\left(\mathrm{IC}_{50}=2.9 \pm\right.$ $0.3 \mu \mathrm{M})$. In the case of $\mathrm{G} 361$, the $\mathrm{IC}_{50}$ values were practically identical for all the tested compounds, including cisplatin $(5.8 \pm 2.4 \mu \mathrm{M})$. On the other hand, the previously reported CuQ was significantly more active on this cell line, with $\mathrm{IC}_{50}=0.8 \pm$ $0.2 \mu \mathrm{M}$. Furthermore, all the tested complexes were found to possess mutually comparable and significantly higher cytotoxicities (ANOVA, $p<0.05$ ) than cisplatin against A2780. The results showed that the complexes were up to $c a$. 35 times more effective than cisplatin; the best $\mathrm{IC}_{50}$ value was determined for 5, i.e. $0.6 \pm 0.1 \mu \mathrm{M}$ (cisplatin: $21.8 \pm 3.9 \mu \mathrm{M}$ ). Cytotoxicity against A2780R was tested with the aim of uncovering the possible ability of the complexes to overcome the resistance of these cells towards cisplatin $\left(\mathrm{IC}_{50}>50 \mu \mathrm{M}\right)$. The complexes showed activities of low micromolar $\mathrm{IC}_{50}(\approx 3 \mu \mathrm{M})$ on this cell line. The difference between the $\mathrm{IC}_{50}$ values determined for A2780 and A2780R was non-significant (ANOVA, $p<0.05$ ) for 1 and 3 , which means that the cytotoxic effect was practically the same against both cell lines (Table 1).

To be considered as an anticancer therapeutic candidate, a compound must be selective for transformed cells over healthy non-transformed cells. To assess the cytotoxicity profiles of the presented complexes, their toxicity towards nonmalignant MRC-5 cells was evaluated. It was found that MRC-5 cells showed rather different sensitivities towards the complexes. Complex 1 was comparably cytotoxic against both transformed and healthy cells, with $\mathrm{IC}_{50}=4.9 \pm 2.7 \mu \mathrm{M}$ for MRC-5. Complex 2 showed ca. $3 \times$ lower toxicity for MRC-5 than $1\left(\mathrm{IC}_{50}=15.9 \pm 1.2 \mu \mathrm{M}\right)$. The $\mathrm{IC}_{50}$ value for complex 3 could not be determined due to its limited solubility in the medium used; therefore, its toxicity can be expressed as $\mathrm{IC}_{50}>25 \mu \mathrm{M}$. However, the result for 3 suggests that its cytotoxicity against cancer cells is $c a$. an order of magnitude higher than its cytotoxicity against healthy cells. The best cytotoxicity profile was found for $\mathbf{5}$, which was non-toxic to MRC-5 up to the highest tested concentration $\left(\mathrm{IC}_{50}>50 \mu \mathrm{M}\right.$ ). The selectivity index (SI) for $\mathbf{5}$, calculated as the ratio of $\mathrm{IC}_{50}$ (non-malignant cells)/ $\mathrm{IC}_{50}(\mathrm{~A} 2780)$, is therefore higher than $c a$. 80, as compared to $c a$. 2 for cisplatin and $\mathrm{SI} \approx$ 40 for $[\mathrm{Cu}$ (qui)(phen) $] \mathrm{BF}_{4}$ (with $\mathrm{IC}_{50}=20.4 \pm 1.2 \mu \mathrm{M}$ against primary human hepatocytes)..$^{22}$ Based on the presented results, it can be suggested that the 2-(3,5-dichloro-4-amino)phenyl and 7-alkylcarboxamido substitutions introduced on the qui skeleton resulted in a beneficial cytotoxic profile in the cases of compounds 3 and $\mathbf{5}$, but not in the cases of $\mathbf{1}$ and $\mathbf{2}$, therefore highlighting the importance of suitable structural modifications of the $O, O$-ligand in this type of copper(II) complex. The results of this study clearly showed that optimization of the composition of Cu-quinolinonato complexes can lead to compounds with increased anticancer effects and simultaneously increased selectivity, which is connected with the reduction of negative side effects.

Table 1 The results of the in vitro cytotoxicity testing of 1 to 5 and cisplatin against human cell lines. Cells were treated with the tested complexes for $24 \mathrm{~h}$; the measurements were performed in triplicate, and cytotoxicity experiments were repeated in three different cell passages; the data are expressed as $\mathrm{IC}_{50} \pm \mathrm{SD}^{a}(\mu \mathrm{M})$

\begin{tabular}{|c|c|c|c|c|c|c|c|}
\hline Compound & HOS & MCF7 & HeLa & G361 & $\mathrm{A} 2780$ & $\mathrm{~A} 2780 \mathrm{R}$ & MRC-5 \\
\hline 1 & $3.3 \pm 1.3$ & $5.5 \pm 2.5$ & $3.2 \pm 0.3$ & $3.5 \pm 0.1$ & $1.0 \pm 0.6$ & $2.9 \pm 1.2$ & $4.9 \pm 2.7$ \\
\hline 2 & $4.6 \pm 0.2$ & $7.1 \pm 2.6$ & $3.0 \pm 1.1$ & $3.7 \pm 0.5$ & $1.3 \pm 0.4$ & $4.4 \pm 0.6$ & $15.9 \pm 1.2$ \\
\hline 3 & $7.1 \pm 1.6$ & $>10$ & $4.1 \pm 0.8$ & $3.1 \pm 0.4$ & $1.9 \pm 0.2$ & $2.5 \pm 0.7$ & $>25$ \\
\hline 4 & $>5$ & $>5$ & n.t. & n.t. & n.t. & n.t. & n.t. \\
\hline 5 & $6.7 \pm 2.5$ & $31.9 \pm 6.4$ & $2.7 \pm 0.5$ & $3.2 \pm 0.6$ & $0.6 \pm 0.1$ & $3.4 \pm 0.2$ & $>50$ \\
\hline Cisplatin & $18.9 \pm 1.7$ & $17.9 \pm 3.5$ & $>50$ & $5.8 \pm 2.4$ & $21.8 \pm 3.9$ & $>50$ & $>50$ \\
\hline
\end{tabular}

${ }^{a}$ n.t. $=$ not tested (due to inactivity in the primary cytotoxicity testing against HOS and MCF7 up to the concentration limited by solubility in the used medium). 


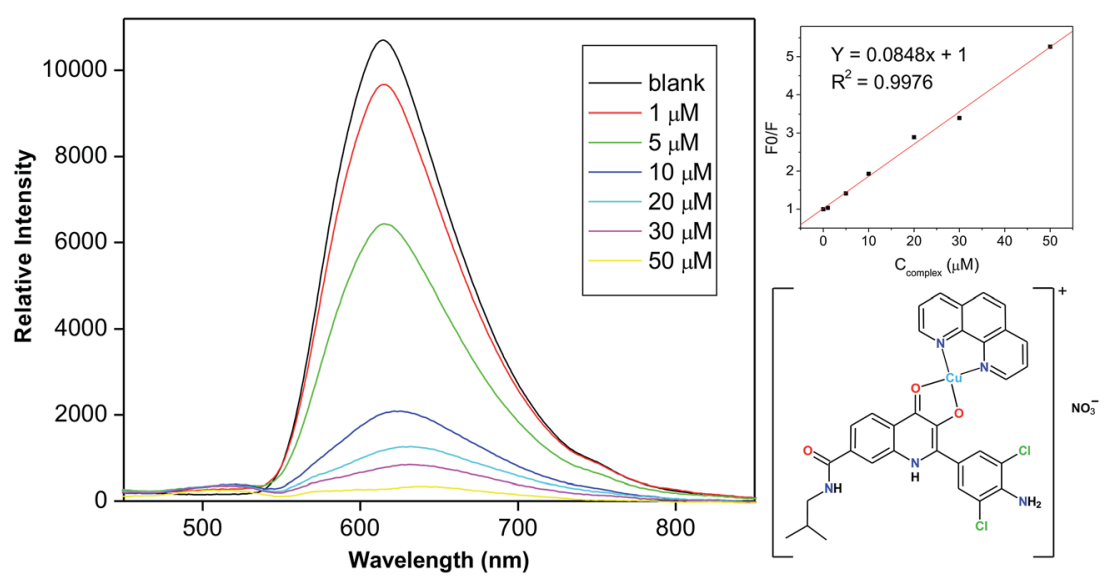

Fig. 3 The results of the fluorescence ethidium bromide (EB) displacement titration assay showing the fluorescence quenching of the EB-DNA system upon the addition of complex 2.

\subsection{Interaction with CT-DNA assessed by fluorescence ethidium bromide (EB) displacement assay}

Ethidium bromide (EB) is a typical intercalator of DNA, because its planar phenanthridine ring is inserted between two adjacent base pairs. The formation of the intercalation manifests itself by the increase of the fluorescence intensity of the formed EB-DNA supramolecular complex up to 24 -fold. ${ }^{35,36}$ This interaction is, however, competitive; when a suitable intercalator is added to the EB-DNA supramolecular complex, some of the EB molecules are substituted and fluorescence quenching is observed. ${ }^{37}$ Therefore, $\mathrm{Cu}^{\mathrm{II}}$ complexes $\mathbf{1 - 5}$ were gradually added to the EB-DNA system with increasing concentration $(1-50 \mu \mathrm{M})$. The emission of the EB-DNA system upon the addition of complex $\mathbf{1}$ is shown in Fig. 3. The results of mathematical analysis of the quenching curves (Table 2) indicated that all the complexes were able to bind to CT-DNA, with apparent binding constants $\left(K_{\text {app }}\right)$ between $1.6 \times 10^{6} \mathrm{M}^{-1}(5)$ and $2.7 \times 10^{7} \mathrm{M}^{-1}(\mathbf{1})$.

\section{6. pUC-19 plasmid DNA cleavage}

To obtain deeper insight into the mechanisms responsible for the cytotoxicity of the tested copper(II) complexes, the representative complex $\mathbf{5}$ was tested to determine its ability to behave as a chemical nuclease under conditions of oxidative stress, in this case represented by a mixture of hydrogen peroxide and a reducing agent (L-ascorbic acid). This model was selected based on the well-known fact that the overdriven metabolism in tumour cells generates considerable amounts of reactive oxygen and nitrogen species, ${ }^{38}$ such as superoxide anionic radicals or hydrogen peroxide, which can generate highly-toxic hydroxyl species and/or other highly reactive metal-containing species by the Fenton reaction. ${ }^{39}$ These highly-reactive species such as hydroxyl are able to cause irreversible damage to the structure of double-stranded DNA (dsDNA); for example, they can induce the decoupling of nitrogen bases, nick one polynucleotide chain, or cleave both strands of DNA. ${ }^{40}$ A relatively small circular dsDNA sequence from the pUC19 plasmid was used as a model object, and the ability of the selected representative complex 5 to oxidatively cleave the polynucleotide chains in the presence of a large excess of hydrogen peroxide was monitored by gel electrophoresis, which allowed qualitative and quantitative evaluation of the different forms of modified DNA (see Fig. 4). The quantitative parameter of total DNA cleavage was calculated as the percentage of the integrated densities of the cleaved forms (OC-form $+2 \times \mathrm{L}$-form) from the sum of integrated densities of all the identified forms of DNA (CCC-form + OC-form $+2 \times$ L-form). The results of the quantification are presented in Table 3.

The results of the cleavage experiments showed the remarkable ability of complex 5 to cleave the DNA by an oxidative mechanism in the presence of a reducing agent (L-ascorbic acid); even at the smallest concentration used $(20 \mu \mathrm{M})$, the complete cleavage of DNA molecules to small fragments occurred, leaving no trace of uncleaved DNA in the electrophoretograms (see lanes $4-6$ and $10-12$ in Fig. 4). At higher concentrations of the complex, the DNA fragments were cross-linked into structures of higher order (and lower electrophoretic mobility); therefore, a smear can be detected in the electrophoretogram (see lanes 13-18 in Fig. 4). Complex 5, however, showed the ability to cleave the polynucleotide chains of dsDNA also without the addition of the reducing agent, reaching DNA cleavage levels of up to $c a .80 \%$ at $100 \mu \mathrm{M}$ concentration. At a concentration of $200 \mu \mathrm{M}$, even in the absence of reducing agent, complete cleavage of the DNA occurred (see lanes 16 to 18 in Fig. 4).

Table 2 The results of the EB-DNA fluorescence quenching experiments, including the values of the Stern-Volmer quenching constant $\left(K_{\mathrm{sv}}\right)$ and apparent binding constant $\left(K_{\mathrm{app}}\right)\left[\mathrm{M}^{-1}\right]$

\begin{tabular}{lll}
\hline Compound & $K_{\mathrm{SV}}$ & $K_{\mathrm{app}}{ }^{a}$ \\
\hline $\mathbf{1}$ & $5.3 \times 10^{5}$ & $2.7 \times 10^{7}$ \\
$\mathbf{2}$ & $8.5 \times 10^{4}$ & $4.2 \times 10^{6}$ \\
$\mathbf{3}$ & $8.5 \times 10^{4}$ & $4.3 \times 10^{6}$ \\
$\mathbf{5}$ & $6.6 \times 10^{4}$ & $3.3 \times 10^{6}$ \\
$\mathbf{5}$ & $3.2 \times 10^{4}$ & $1.6 \times 10^{6}$
\end{tabular}

${ }^{a}$ the concentration of EB was $5 \mu \mathrm{M}$. 


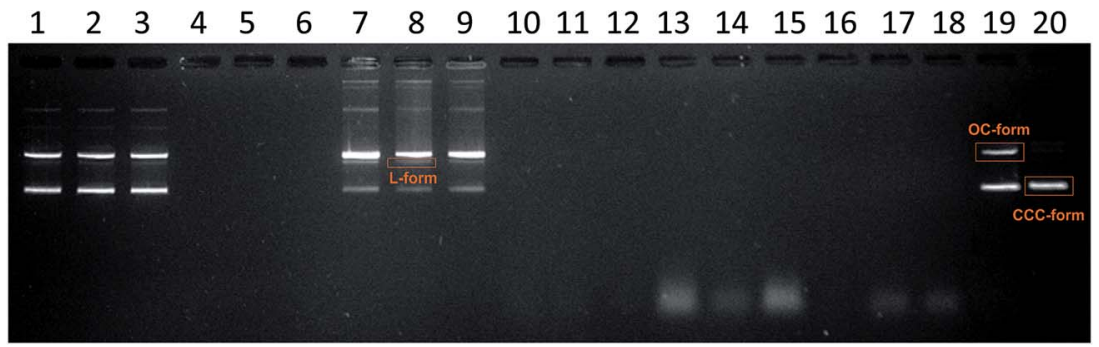

Fig. 4 The electrophoretogram depicting the cleavage of pUC19 plasmid DNA by complex 5 in the presence of hydrogen peroxide. The three basic forms of plasmid DNA are identified as supercoiled DNA (CCC-form), open circular form (OC-form), and linear form (L-form). Lanes 1-3, 79 and 13-15 represent the products of the cleavage of pUC19 plasmid induced by complex 5 applied in concentrations of $20 \mu \mathrm{M}, 100 \mu \mathrm{M}$, and $200 \mu \mathrm{M}$, respectively, without the addition of ascorbic acid as a reducing agent. Lanes 4-6, 10-12 and 16-18 represent the products of the cleavage of pUC19 plasmid induced by complex 5 applied in concentrations of $20 \mu \mathrm{M}, 100 \mu \mathrm{M}$, and $200 \mu \mathrm{M}$, respectively, with the addition of ascorbic acid as a reducing agent (complete cleavage in all cases). Lane 19 represents a blank sample (the mixture of pUC19 plasmid and hydrogen peroxide) and lane 20 represents the native pUC19 plasmid.

In conjunction with the abovementioned presented results of the EB-displacement method, in which complex 5 showed the ability to effectively substitute ethidium bromide at the intercalating sites in the minor groove of the DNA double helix, it can be speculated that the mechanism of DNA-cleavage mediated by this complex is based on sequence non-specific interactions between the cations $\left[\mathrm{Cu}(\text { qui)(phen) }]^{+}\right.$, or similar cationic species containing the $\{\mathrm{Cu}($ phen $)\}$ residue (see Section 3.7, interactions with sulphur-containing biomolecules assessed by ESI-MS) and the phosphate moieties; the mechanism may also be partly due to intercalation in the minor groove of the double helical DNA, ${ }^{41,42}$ the reduction of $\mathrm{Cu}$ (II) to $\mathrm{Cu}(\mathrm{I})$, and the Fenton reaction-mediated production of reactive oxygen species that are able to cleave the polynucleotide chains, probably at the $\mathrm{C} 1^{\prime}$ or $\mathrm{C}^{\prime}{ }^{\prime}$ sites of the adjacent deoxyribose moieties. ${ }^{40}$

\subsection{Interactions with sulphur-containing biomolecules assessed by ESI-MS}

With the aim of describing the interactions of the complexes (using the example of the representative complex 5) in solutions that mimic the conditions of the real physiological environment, we performed mass spectrometric evaluations of the interacting systems, containing $10 \mu \mathrm{M}$ of complex 5 and a mixture of L-cysteine and L-glutathione at physiological concentrations (290 $\mu \mathrm{M}$ and $6 \mu \mathrm{M}$, respectively). ${ }^{30}$ The mass spectra of this system were obtained immediately after mixing the components $(0 \mathrm{~h})$ and then after 1,12 , and $24 \mathrm{~h}$. The most pronounced changes were found after $24 \mathrm{~h}$ of interaction (see Fig. 5). The mass spectrum of the interacting system was compared to that of complex $\mathbf{5}$, dissolved in methanol : water $(1: 1, \mathrm{v} / \mathrm{v})$ (see Fig. 5B), which contained a rich variety of peaks corresponding to the ionic species derived from the phen ligand

Table 3 The results of the DNA-cleavage experiments

\begin{tabular}{|c|c|c|c|c|c|c|}
\hline Lane & Concentration of $\mathbf{5}$ & Conditions & CCC $[\%]$ & $\mathrm{L}[\%]$ & $\mathrm{OC}[\%]$ & $\begin{array}{l}\text { Average DNA } \\
\text { cleavage [\%] }\end{array}$ \\
\hline 1 & $20 \mu \mathrm{M}$ & W/o L-ascorbic acid & $57.1 \%$ & $6.9 \%$ & $36.0 \%$ & 46.3 \\
\hline 2 & & & $58.1 \%$ & $5.7 \%$ & $36.2 \%$ & \\
\hline 3 & & & $56.8 \%$ & $7.7 \%$ & $35.5 \%$ & \\
\hline 4 & $20 \mu \mathrm{M}$ & With L-ascorbic acid & $0 \%$ & $0 \%$ & $0 \%$ & 100 \\
\hline 5 & & & $0 \%$ & $0 \%$ & $0 \%$ & \\
\hline 6 & & & $0 \%$ & $0 \%$ & $0 \%$ & \\
\hline 7 & $100 \mu \mathrm{M}$ & W/o L-ascorbic acid & $28.7 \%$ & $13.8 \%$ & $57.5 \%$ & 75.6 \\
\hline 8 & & & $24.7 \%$ & $18.0 \%$ & $57.3 \%$ & \\
\hline 9 & & & $29.7 \%$ & $10.3 \%$ & $60.0 \%$ & \\
\hline 10 & $100 \mu \mathrm{M}$ & With L-ascorbic acid & $0 \%$ & $0 \%$ & $0 \%$ & 100 \\
\hline 11 & & & $0 \%$ & $0 \%$ & $0 \%$ & \\
\hline 12 & & & $0 \%$ & $0 \%$ & $0 \%$ & \\
\hline 13 & $200 \mu \mathrm{M}$ & W/o L-ascorbic acid & $0 \%$ & $0 \%$ & $0 \%$ & 100 \\
\hline 14 & & & $0 \%$ & $0 \%$ & $0 \%$ & \\
\hline 15 & & & $0 \%$ & $0 \%$ & $0 \%$ & \\
\hline 16 & $200 \mu \mathrm{M}$ & With L-ascorbic acid & $0 \%$ & $0 \%$ & $0 \%$ & 100 \\
\hline 17 & & & $0 \%$ & $0 \%$ & $0 \%$ & \\
\hline 18 & & & $0 \%$ & $0 \%$ & $0 \%$ & \\
\hline 19 & Blank & & $68.1 \%$ & $0 \%$ & $31.9 \%$ & 31.9 \\
\hline 20 & Native plasmid & & $94.7 \%$ & $1.2 \%$ & $4.1 \%$ & 6.4 \\
\hline
\end{tabular}



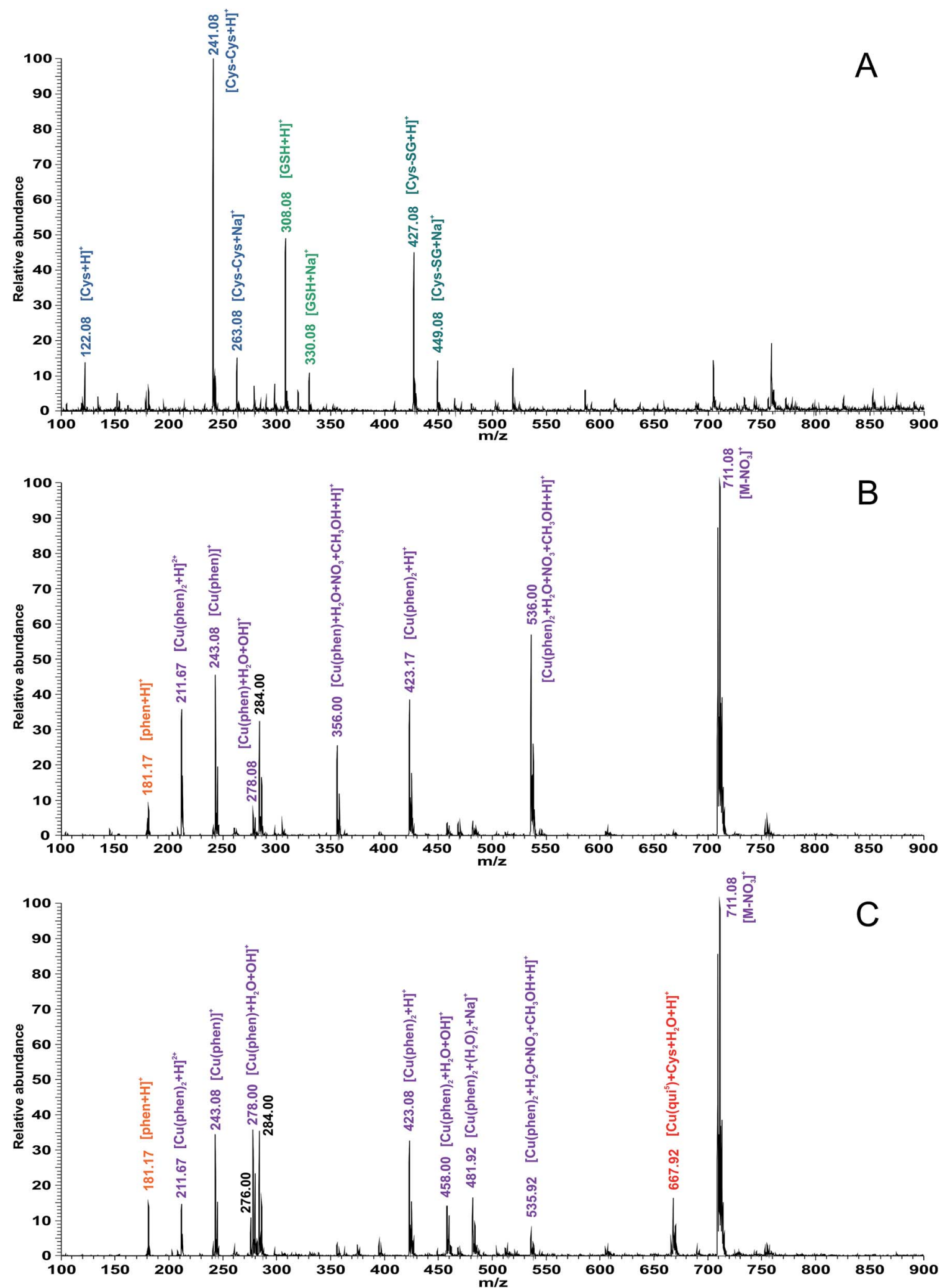

Fig. 5 Results of the ESI-MS studies of the interactions of complex 5 with physiological concentrations of L-cysteine and L-glutathione. ESI-MS spectra of the mixture containing physiological concentrations of L-cysteine and L-glutathione (A), a $10 \mu \mathrm{M}$ solution of complex 5 in methanol : water $(1: 1, v / v) 24 \mathrm{~h}$ after preparation (B), and the interacting system containing complex 5 (at a concentration of $10 \mu \mathrm{M}$ ), L-cysteine (at a concentration of $290 \mu \mathrm{M}$ ) and reduced glutathione (at a concentration of $6 \mu \mathrm{M}$ ) (C). The identified ionic species for the selected peaks are indicated. 
(at $181.17 \mathrm{~m} / \mathrm{z}$ ) and solvated $\{\mathrm{Cu}($ phen) $\}$ residues, such as $\left[\mathrm{Cu}(\text { phen })_{2}+\mathrm{H}\right]^{2+}$ at $211.67 \mathrm{~m} / \mathrm{z},[\mathrm{Cu}(\text { phen })]^{+}$at $243.08 \mathrm{~m} / \mathrm{z}$, $\left[\mathrm{Cu}(\text { phen })+\mathrm{H}_{2} \mathrm{O}+\mathrm{OH}\right]^{+}$at $278.08 \mathrm{~m} / z$, $\left[\mathrm{Cu}(\right.$ phen $)+\mathrm{H}_{2} \mathrm{O}+\mathrm{NO}_{3}+$ $\left.\mathrm{CH}_{3} \mathrm{OH}+\mathrm{H}\right]^{+}$at $356.00 \mathrm{~m} / \mathrm{z}$, $\left[\mathrm{Cu}(\text { phen })_{2}+\mathrm{H}\right]^{+}$at $423.17 \mathrm{~m} / \mathrm{z}$, $\left[\mathrm{Cu}(\text { phen })_{2}+\mathrm{H}_{2} \mathrm{O}+\mathrm{NO}_{3}+\mathrm{CH}_{3} \mathrm{OH}+\mathrm{H}\right]^{+}$at $536.00 \mathrm{~m} / \mathrm{z}$, and $[\mathrm{M}-$ $\left.\mathrm{NO}_{3}\right]^{+}$at $711.08 \mathrm{~m} / \mathrm{z}$. In addition to the abovementioned ionic species, the mass spectrum of the interacting system (see Fig. 5C) containing L-cysteine and L-glutathione showed one additional set of peaks corresponding to the interacting species containing the L-cysteine residue, with the composition $\left[\mathrm{Cu}\left(\mathrm{qui}^{5}\right)+\mathrm{Cys}+\mathrm{H}\right]^{+}$, at $667.92 \mathrm{~m} / \mathrm{z}$.

The described set of interactions in solution may contribute significantly to the behaviour of the prepared complexes in biological systems, leading to their higher affinity in the context of DNA binding in the form of the species containing $\{\mathrm{Cu}($ phen $)\}$. These findings are in agreement with those reported in our previous study. ${ }^{20-22}$

\section{Conclusions}

Five copper(II) mixed-ligand complexes with the general composition $\left[\mathrm{Cu}\left(\right.\right.$ qui $\left.^{x}\right)($ phen $\left.)\right] \mathrm{NO}_{3} \cdot y \mathrm{H}_{2} \mathrm{O}$ (1-5), where $\mathrm{Hqui}^{x}$ stands for variously $\mathrm{N}$-substituted 2-(4-amino-3,5-dichlorophenyl)-3-hydroxy-4(1H)-quinolinone-7-carboxamides; phen = 1,10-phenanthroline and $y=0$ or 1 , were prepared, thoroughly characterized and screened for their in vitro cytotoxicity against a panel of human cancer cell lines (HOS, MCF7, HeLa, G361, A2780, and A2780R). In addition, their toxicity to healthy cells was evaluated on a non-malignant lung fibroblast cell line, MRC-5. The presented complexes, except for $\mathbf{4}$, were found to be potent in vitro anticancer agents; complex $\mathbf{5}$ was found to have the best $\mathrm{IC}_{50}$ value, i.e. $0.6 \pm 0.1 \mu \mathrm{M}$ against $\mathrm{A} 2780$. Moreover, complex 5 showed a very favourable selectivity index, calculated as the ratio of $\mathrm{IC}_{50}(\mathrm{MRC}-5) / \mathrm{IC}_{50}(\mathrm{~A} 2780)$, reaching a value higher than ca. 80. Complexes 1-5 were able to bind to CT-DNA, as evidenced by significant florescence quenching of the ethidium bromide-DNA system, with binding constants comparable to that of ethidium bromide. Furthermore, pUC19 plasmid DNA cleavage experiments showed the ability of the prepared complexes to act as chemical nucleases in the presence of hydrogen peroxide, and the addition of reducing agent (L-ascorbic acid) significantly increased their pro-oxidative effects. The results of the mass spectrometric evaluation of the interactions of the representative complex 5 with sulphurcontaining biomolecules confirmed the ability of the complex to interact with physiological levels of L-cysteine and simultaneously suggested that the species responsible for the biological activities of the prepared complexes may be $[\mathrm{Cu} \text { (qui)(phen) }]^{+}$or similar cationic species containing the $\{\mathrm{Cu}(\mathrm{phen})\}$ moiety.

The current study unambiguously demonstrated the importance of suitable structural modifications of the $O, O$-ligands in Casiopeínas®-like copper(II) complexes. The results of the most promising complex, 5, suggested that the introduced $7-(p$-xylyl $)$ carboxamido-substitution on the qui skeleton resulted in a more beneficial cytotoxic profile, with comparable anticancer activity and significantly increased selectivity towards cancer cells over non-malignant cells. In conclusion, it can be pointed out that the presented results represent a successful next step in the optimization of the composition of $\mathrm{Cu}$-quinolinonato complexes, leading to potentiation of their anticancer activity and, concurrently, suppression of their negative side-effects.

\section{Acknowledgements}

The authors would like to acknowledge the financial support from the National Program of Sustainability I (LO1305) of the Ministry of Education, Youth and Sports of the Czech Republic and Palacký University (PrF_2015_019). We are also grateful to Ms Kateřina Kubešová for help with cytotoxicity testing, Dr Bohuslav Drahoš for help with mass spectrometry experiments and $\mathrm{Mr}$ Jakub Hutyra for performing DNA cleavage experiments.

\section{References}

1 L. R. Kelland and N. P. Farrell, Platinum Based Drugs in Cancer Therapy, Humana Press, Totowa, NJ, USA, 2000.

2 M. Gielen and E. R. T. Tiekink, Metallotherapeutic Drugs and Metal-Based Diagnostic Agents, John Wiley \& Sons, Ltd., Chichester, UK, 2005.

3 E. Alessio, Bioinorganic Medicinal Chemistry, Wiley-VCH Verlag GmbH \& Co. KGaA, Weinheim, Germany, 2011.

4 P. Heffeter, U. Jungwirth, M. Jakupec, C. Hartinger, M. Galanski, L. Elbling, M. Micksche, B. Keppler and W. Berger, Drug Resist. Updates, 2008, 11, 1.

$5 \mathrm{X}$. Y. Wang and Z. J. Guo, New Trends and Future Developments of Platinum-Based Antitumor Drugs in Bioinorganic Medicinal Chemistry, ed. E. Alessio, WILEYVCH Verlag GmbH \& Co. KGaA, Weinheim, 2011.

6 C. X. Zhang and S. J. Lippard, Curr. Opin. Chem. Biol., 2003, 7, 481.

7 M. C. Linder, Biochemistry of Copper, Plenum Press, New York, 1991.

8 J. M. C. Gutteridge, Med. Biol., 1985, 63, 41-42.

9 W. Zhou, X. Wang, M. Hu, C. Zhu and Z. Guo, Chem. Sci., 2014, 5, 2761.

10 S. Tardito, A. Barilli, I. Bassanetti, M. Tegoni, O. Bussolati, R. Franchi-Gazzola, C. Mucchino and L. Marchio, J. Med. Chem., 2012, 55, 10448.

11 D. Palanimuthu, S. V. Shinde, K. Somasundaram and A. G. Samuelson, J. Med. Chem., 2013, 5, 722.

12 C. Marzano, M. Pellei, F. Tisato and C. Santini, Anti-Cancer Agents Med. Chem., 2009, 9, 185.

13 F. P. Dwyer, E. Mayhew, E. M. Roe and A. Shulman, Br. J. Cancer, 1965, 19, 195.

14 C. Mejia and L. Ruiz-Azuara, Pathol. Oncol. Res., 2008, 14, 467.

15 M. E. Bravo-Gomez, J. C. Garcia-Ramos, I. Garcia-Mora and L. Ruiz-Azuara, J. Inorg. Biochem., 2009, 103, 299.

16 L. Becco, A. Rodriguez, M. E. Bravo, M. J. Prieto, L. RuizAzuara, B. Garat, V. Moreno and D. Gambino, J. Inorg. Biochem., 2012, 109, 49.

17 A. G. Gutierrez, A. Vazquez-Aguirre, J. C. Garcia-Ramos, M. Flores-Alamo, E. Hernandez-Lemus, L. Ruiz-Azuara and C. Mejia, J. Inorg. Biochem., 2013, 126, 17. 
18 G. Vértiz, L. E. García-Ortuno, J. P. Bernal, M. E. BravoGómez, E. Lounejeva, A. Huerta and L. Ruiz-Azuara, Fundam. Clin. Pharmacol., 2014, 28, 78.

19 L. Becco, J. C. García-Ramos, L. Ruiz Azuara, D. Gambino and B. Garat, Biol. Trace Elem. Res., 2014, 161, 210.

20 R. Buchtík, Z. Trávníček, J. Vančo, R. Herchel and Z. Dvořák, Dalton Trans., 2011, 40, 9404.

21 R. Buchtík, Z. Trávníček and J. Vančo, J. Inorg. Biochem., 2012, 116, 163.

22 Z. Trávníček, J. Vančo, J. Hošek, R. Buchtík and Z. Dvořák, Chem. Cent. J., 2012, 6, 160.

23 M. Soural, J. Hlaváč, P. Funk, P. Džubák and M. Hajdúch, ACS Comb. Sci., 2011, 13, 39.

24 M. Soural, J. Hlaváč, P. Hradil, I. Fryšová, M. Hajdúch, V. Bertolasi and M. Maloň, Eur. J. Med. Chem., 2006, 41, 467. 25 A. D. Becke, J. Chem. Phys., 1993, 98, 1372.

26 V. Rassolov, J. A. Pople, M. Ratner, P. C. Redfern and L. A. Curtiss, J. Comput. Chem., 2001, 22, 976.

27 V. Shao, L. F. Molnar, Y. Jung, J. Kussmann, C. Ochsenfeld, S. T. Brown, A. T. B. Gilbert, L. V. Slipchenko, S. V. Levchenko, D. P. O'Neill, R. A. DiStasio Jr, R. C. Lochan, T. Wang, G. J. O. Beran, N. A. Besley, J. M. Herbert, C. Y. Lin, T. van Voorhis, S. H. Chien, A. Sodt, R. P. Steele, V. A. Rassolov, P. E. Maslen, P. P. Korambath, R. D. Adamson, B. Austin, J. Baker, E. F. C. Byrd, H. Dachsel, R. J. Doerksen, A. Dreuw, B. D. Dunietz, A. D. Dutoi, T. R. Furlani, S. R. Gwaltney, A. Heyden, S. Hirata, C. P. Hsu, G. Kedziora, R. Z. Khalliulin, P. Klunzinger, A. M. Lee, M. S. Lee, W. Z. Liang, I. Lotan, N. Nair, B. Peters, E. I. Proynov, P. A. Pieniazek, Y. M. Rhee, J. Ritchie, E. Rosta, C. D. Sherrill, A. C. Simmonett, J. E. Subotnik, H. L. Woodcock III, W. Zhang, A. T. Bell, A. K. Chakraborty, D. M. Chipman, F. J. Keil, A. Warshel, W. J. Hehre, H. F. Schaefer, J. Kong, A. I. Krylov,
P. M. W. Gill and M. Head-Gordon, Phys. Chem. Chem. Phys., 2006, 8, 3172.

28 QC Expert 3.2, Statistical software, TriloByte Ltd., Pardubice, Czech Republic, 2009.

29 A. Banerjee, J. Singh and D. Dasgupta, J. Fluoresc., 2013, 23, 745.

30 G. Salemi, M. C. Gueli, M. D'Amelio, V. Saia, P. Mangiapane, P. Aridon, P. Ragonese and I. Lupo, Neurol. Sci., 2009, 30, 361.

31 E. I. Solomon and A. B. P. Lever, Inorganic Electronic Structure and Spectroscopy, Applications and Case Studies, Wiley, New York, 1999, vol. 2.

32 K. Nakamoto, Infrared and Raman Spectra of Inorganic and Coordination Compounds, Part B: Applications in Coordination Organometallic and Bioinorganic Chemistry, 5th edn, Wiley, New York, 1997.

33 A. Barve, A. Kumbhar, M. Bhat, B. Joshi, R. Butcher, U. Sonawane and R. Joshi, Inorg. Chem., 2009, 48, 9120.

34 L. Gasque, G. Medina, L. Ruiz-Ramírez and R. MorenoEsparza, Inorg. Chim. Acta, 1999, 288, 106.

35 D. Suh and J. B. Chaires, Bioorg. Med. Chem., 1995, 3, 723.

36 G. Zhao, H. Lin, S. Zhu, H. Sun and Y. Chen, J. Inorg. Biochem., 1998, 70, 219.

37 R. F. Pasternack, M. Caccam, B. Keogh, T. A. Stephenson, A. P. Williams and E. J. Gibbs, J. Am. Chem. Soc., 1991, 113, 6835.

38 J. C. Tung, J. M. Barnes, S. R. Desai, C. Sistrunk, M. W. Conklin, P. Schedin, K. W. Eliceiri, P. J. Keely, V. L. Seewaldt and V. M. Weaver, Free Radical Biol. Med., 2015, 79, 269.

39 M. L. Kremer, Phys. Chem. Chem. Phys., 1999, 1, 3595.

40 P. C. Dedon, Chem. Res. Toxicol., 2008, 21, 206.

41 A. S. Kumbhar, S. G. Damle, S. T. Dasgupta, S. Y. Rane and A. S. Kumbhar, J. Chem. Res., Synop., 1999, 98.

42 A. Silvestri, G. Barone, G. Ruisi, M. T. Lo Giudice and S. Tumminello, J. Inorg. Biochem., 2004, 98, 589. 